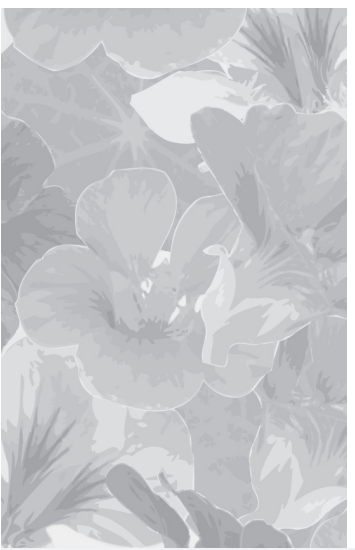

\title{
Częstość występowania chorób skóry w losowej grupie dorosłych Polaków
}

\section{Frequency of skin diseases in a random sample of adult Poles}

\author{
Radosław Śpiewak \\ Instytut Dermatologii, Kraków \\ Estetol Med Kosmetol 2012; 2(2): 50-53 \\ DOI: http://dx.doi.org/10.14320/EMK.2012.010
}

\section{Streszczenie}

Niewiele wiadomo na temat rozpowszechnienia chorób skóry w generalnej populacji Polaków. Cel: Ocena częstości występowania chorób skóry w losowej próbie populacji generalnej. Materiat i metody: W badaniach wzięło udział 145 losowo wybranych dorosłych mieszkańców gminy wiejskiej we wschodniej Polsce: 67 kobiet i 78 mężczyzn w wieku 18-75 (mediana 43) lat. Dane na temat chorobowości życiowej na choroby skóry (choroba obecna w przeszłości lub w chwili badania) zostałyzebrane za pomocą standardowego kwestionariusza wypetnianego przez lekarza. Najbardziej prawdopodobne rozpoznanie było ustalane na miejscu przez specjalistę dermatologa na podstawie danych z wywiadu, morfologii zmian skórnych (jeśli wystepowały w chwili badania), a także kart informacyjnych i zaświadczeń z wcześniejszego leczenia okazanych przez uczestników badań. Wyniki: Spośród 145 badanych, 42 (29,0\%; 95\%Cl: 21,6$36,3 \%$ ) zgłaszało występowanie chorób skóry w przeszłości lub obecnie. Najczęściej zgłaszano objawy wyprysku/zapalenia skóry (10,3\%; $95 \% \mathrm{Cl}: 5,4-15,3 \%)$, a nasteepnie trądziku (4,8\%; 95\% Cl: $1,3-8,3 \%)$, grzybicy skóry lub paznokci $(3,4 \% ; 95 \% \mathrm{Cl}: 0,5-6,4 \%)$, pokrzywki oraz tuszczycy (w obu przypadkach 2,8\%; $95 \% \mathrm{Cl}$ : 0,1-5,4\%). Skórne reakcje polekowe różnego typu zgtosito 2,1\% badanych (95\%Cl: 0,0-4,4\%). Na podstawie porównania uzyskanych częstości z danymi dla innych populacji można wysnuć przypuszczenie, że niektóre problemy skórne były bagatelizowane lub przemilczane przez respondentów. Zatem uzyskane częstości mogą bardziej odzwierciedlać czesstość chorób, które powodowały uciążliwość dla badanych i dlatego zostały zapamiętane przez respondentów, niż częstość wszystkich chorób skóry, również tych mniej dokuczliwych. Wnioski: Co trzeci dorosty Polak aktualnie choruje bądź chorowat w przesztości na choroby skóry, najczęściej na choroby z kręgu wyprysku lub trądziku.

Stowa kluczowe: dermatoepidemiologia, epidemiologia, choroby skóry, populacja generalna, badania ankietowe, badania lekarskie

\begin{abstract}
Little is known about the epidemiology of skin diseases in the general population of Poland. Aim: To assess the prevalence of skin diseases in a random sample of the general population. Material and methods: 145 randomly selected adults from a rural community in Eastern Poland participated in the study on a voluntary basis: 67 women and 78 men aged 18-75 years (median 43 years). Data on the lifetime prevalence of skin diseases (past or present disease) were collected using a standardised, doctor-administered questionnaire. The most probable diagnosis of skin disease was established by a dermatologist, based on information from the questionnaire, morphology of skin changes (if present upon the examination), and medical records from previous treatment presented by the participants. Results: Of the 145 persons studied, $42(29.0 \% ; 95 \% \mathrm{Cl}: 21.6-36.3 \%)$ reported having any skin disease in the past or at present. Most frequently, they had experienced symptoms of eczema/dermatitis (10.3\%; $95 \% \mathrm{Cl}: 5.4-15.3 \%)$, acne $(4.8 \% ; 95 \% \mathrm{Cl}$ : 1.3-8.3\%), tinea/onychomycosis (3.4\%; $95 \% \mathrm{Cl}: 0.5-6.4 \%)$, urticaria and psoriasis $(2.8 \%$ each; $95 \% \mathrm{Cl}: 0.1-5.4 \%)$. Cutaneous adverse drug reactions were reported by $2.1 \%$ ( $95 \% \mathrm{Cl}: 0.0-4,4 \%)$. Some of the skin problems seemed to be played down by the rural residents when comparing with data from other populations. These figures, therefore, may reflect the frequency of skin diseases perceived as a problem and remembered by the people rather than all skin problems, including minor ones. Conclusion: Every third adult person in Poland has had a skin disease ever in life, most frequently various forms of eczema or acne.
\end{abstract}

Keywords: dermatoepidemiology, epidemiology, skin diseases, general population, questionnaire study, medical examinations

Copyright $\odot 2012$ the Authors (text) and Radostaw Śpiewak (layout \& journal compilation). All rights reserved.

Dermatoepidemiologia to nowy dział medycyny powstały na styku dermatologii i epidemiologii. Zajmuje się częstością występowania chorób skóry w populacjach, jak również identyfikacją czynników ryzyka oraz grup ryzyka. Dermatoepidemiologia jest jednym z głównych filarów dermatologii opartej na dowodach naukowych [1]. Dziedzina ta powstała w odpowiedzi na palący problem braku danych epidemiologicznych na temat występowania chorób skóry w populacji generalnej. Brak danych na temat rozpowszechnienia chorób skóry w populacji generalnej utrudnia racjonalne planowanie w zakresie usług medycznych i zdrowia publicznego.

\section{Cel}

Celem niniejszej pracy była ocena częstości występowania chorób skóry w losowej próbie dorosłych Polaków.

\section{Materiat i metody}

W latach 1998-2000 prowadzono badania nad występowaniem chorób skóry prowokowanych przez pracę wśród mieszkańców 37 losowo wybranych gospodarstw rolnych położonych w 9 wsiach należących do gminy Wilków w województwie lubelskim. W badaniach wzięło udział 145 losowo wybranych dorosłych 
mieszkańców gminy wiejskiej we wschodniej Polsce: 67 kobiet i 78 mężczyzn w wieku 18-75 (mediana 43) lat. Wszyscy mieszkańcy zaproszeni do badania zgodzili się wziąć w nim udział. Badania przeprowadził specjalista dermatolog stosując wcześniej opisany kwestionariusz [2], dotyczący objawów skórnych prowokowanych przez pracę, który w odniesieniu do każdego objawu lub dolegliwości skórnej zawierał dodatkowe pytania służące ścisłemu rozgraniczeniu między problemami skórnymi prowokowanymi przez pracę a niezawodowymi chorobami skóry. Dermatolog ustalał najbardziej prawdopodobne rozpoznanie na podstawie udzielonych odpowiedzi, a w przypadku obecności zmian skórnych w czasie badania, były one również uwzględniane w procesie diagnostycznym, podobnie jak przedstawiane przez badanych zaświadczenia lekarskie oraz karty informacyjne z wcześniejszego leczenia chorób skóry. Wyniki badań nad częstością występowania dolegliwości skórnych prowokowanych przez pracę zostały opublikowane bezpośrednio po zakończeniu badań [3], natomiast dane na temat chorób niezawodowych są przedmiotem niniejszego artykułu.

\section{Wyniki}

Spośród 145 badanych, 42 osoby (29,0\%; 95\%CI: 21,6$36,3 \%$ ) zgłaszały występowanie niezawodowych chorób skóry w przeszłości lub obecnie. W badanej grupie najczęściej stwierdzano choroby z kręgu wyprysku oraz trądziku (tabela 1).

Tabela 1. Rozpoznania (grupy rozpoznań) w badanej grupie

\begin{tabular}{l|c|c}
\multicolumn{1}{c|}{$\begin{array}{c}\text { Najbardziej prawdopodobne rozpoznanie } \\
\text { (grupa rozpoznań) }\end{array}$} & Częstość & $\begin{array}{c}\mathbf{9 5 \%} \\
\text { przedzial } \\
\text { ufności [4] }\end{array}$ \\
\hline Wyprysk/zapalenie skóry & $10,3 \%$ & $5,4-15,3 \%$ \\
\hline Trądzik & $4,8 \%$ & $1,3-8,3 \%$ \\
\hline Grzybica (skóra, paznokcie) & $3,4 \%$ & $0,5-6,4 \%$ \\
\hline Pokrzywka & $2,8 \%$ & $0,1-5,4 \%$ \\
\hline Łuszczyca & $2,8 \%$ & $0,1-5,4 \%$ \\
\hline Skórne reakcje polekowe różnego typu & $2,1 \%$ & $0,0-4,4 \%$
\end{tabular}

\section{Dyskusja}

Jak dotąd nie było opublikowanych danych na temat częstości występowania chorób skóry w populacji generalnej Polaków. Uzyskane wyniki nie odbiegają znaczne od danych z innych krajów. Występowanie objawów wyprysku kiedykolwiek w życiu zostało zgłoszone przez jednego na dziesięciu uczestników badań. Autor świadomie zrezygnował tutaj z pokusy zgadywania rozpoznań poszczególnych typów wyprysku (kontaktowy alergiczny, z podrażnienia, atopowy itd.), ponieważ rozróżnienie tych chorób na podstawie wywiadu, a nawet objawów klinicznych jest w wielu przypadkach praktycznie niemożliwe [5,6]. Jednak globalna częstość wyprysku w tej grupie (około 10\%) mieści się w zakresie częstości dla poszczególnych rodzajów wyprysku opisywanych w literaturze. Między innymi, chorobowość życiową dla wyprysku atopowego w różnych krajach szacowano na 5-23\%, alergicznego wyprysku kontaktowego na $17 \%$, a wyprysku z podrażnienia na $13 \%$ (przegląd w [7]). Analizując dane epidemiologiczne należy mieć na uwadze częste współwystępowanie różnych chorób z kręgu wyprysku, a także wspomnianą wyżej trudność jednoznacznego rozróżnienia między poszczególnymi chorobami z kręgu wyprysku. Występowanie kiedykolwiek w życiu (chorobowość życiowa) objawów sugerujących trądzik zgłaszało bez mała 5\% badanych, co wydaje się wartością bardzo niską w świetle danych z badań populacji Hamburga, w których chorobowość punktową na podstawie badania lekarskiego uczestników oceniono na 27\% [8]. Prawdopodobnie w obecnych badaniach objawy trądziku zapamiętały i zgłosiły jedynie te osoby, dla których stanowił on znaczący problem. Mieszkańcy wsi, szczególnie osoby starsze mogą wykazywać tendencję do bagatelizowania problemów mało dokuczliwych, czy wręcz kosmetycznych. Podobny mechanizm mógł zadziałać w przypadku objawów grzybicy skóry oraz paznokci, zgłaszanych przez nieco ponad 3\% badanych, co znacznie kontrastuje z danymi opublikowanymi przez innych autorów: W badaniach pracowników gospodarstw rolnych w Polsce północnej, samą tylko grzybicę stóp stwierdzono u 21-24\% badanych [9], zaś częstość grzybicy paznokci w populacji Australijczyków oceniano na 2-8\% [10].

W odróżnieniu od trądziku i grzybicy, pokrzywka jest stosunkowo dokuczliwą chorobą i w przypadku przebiegu przewlekłego lub nawrotowego raczej nie umknie uwadze pacjenta. Ze względu na charakterystyczne objawy stosunkowo łatwo jest także zweryfikować rodzaj wykwitów podczas wywiadu, nawet pod ich nieobecność w chwili badania. Zatem częstość występowania kiedykolwiek w życiu objawów pokrzywki zgłaszanych przez uczestników badania na poziomie 2,8\% wydaje się dość wiarygodnym wskaźnikiem. Wartość ta jest wyższa od opisanej w populacji generalnej Niemców chorobowości życiowej na pokrzywkę spontaniczną przewlekłą (1,8\%), a zarazem niższa od chorobowości na pokrzywkę cholinergiczną (11,2\%), można ją zatem interpretować jako wypadkową chorobowości na różne typy pokrzywki. Z powodów podanych w odniesieniu do wyprysku, również i tutaj autor zrezygnował z niezbyt realistycznej w warunkach badania terenowego pokusy różnicowania typów pokrzywek. Dostępne dane epidemiologiczne odnośnie do różnych postaci pokrzywki zostały szczegółowo omówione w [11]. Występowanie objawów łuszczycy kiedykolwiek w życiu zgłaszało w przebadanej populacji 2,8\% osób, co mieści się w zakresie wartości obserwowanych w innych krajach, gdzie chorobowość życiowa na łuszczycę sięga od 0,9\% (USA) do 8,5\% (Norwegia) [12]. 
Niepożądane reakcje polekowe stanowią istotny problem społeczny, który wydaje się narastać wraz rosnącą konsumpcją leków [13]. W niniejszych badaniach 2,1\% uczestników doświadczyło przynajmniej jednego epizodu skórnej reakcji polekowej. W ogólnopolskich badaniach stanu zdrowia uczniów szkół rolniczych, 9,7\% uczestników doświadczyło niepożądanych reakcji polekowych (skórnych lub pozaskórnych), u 6,7\% wystąpiły one po przyjęciu antybiotyków, u 3,0\% po kwasie acetylosalicylowym (aspiryna), a u $1,5 \%$ po pochodnych pirazolonu (metamizol i aminofenazon) [14]. W badaniach z 2007 roku odsetek studentów UJ na kierunku „Zdrowie Publiczne”, którzy przynajmniej raz w życiu doświadczyli niepożądanych reakcji polekowych wynosił aż 30,4\% [15]. Bardziej szczegółowe badania studentów tego samego wydziału 2 lata później wykazały, że 7,8\% studentów doświadczyło reakcji niepożądanych po lekach dostępnych bez recepty, a $38,4 \%$ po lekach wydawanych z przepisu lekarza [13]. $\mathrm{W}$ opisanej $\mathrm{w}$ niniejszym artykule populacji, skórnych reakcji polekowych doświadczyło $2,1 \%$ badanych. W przytoczonych wcześniej badaniach studentów zdrowia publicznego Uniwersytetu Jagiellońskiego odsetek respondentów zgłaszających wystąpienie skórnych reakcji polekowych kiedykolwiek w życiu wynosił 13,3\% w pierwszym badaniu [15] i 0,7\% w drugim [13]. Uzmysławia to znaczną zmienność wyników w niewielkich grupach i potrzebę prowadzenia badań przekrojowych większych grup. Grupa przedstawiona w niniejszym artykule również była stosunkowo nieliczna, co ogranicza siłę wnioskowania na temat rozpowszechnienia chorób skóry w populacji generalnej. Ograniczeniem metodycznym badań było również oparcie wyników na danych z wywiadu zbieranego przez lekarza w warunkach ,polowych”, bez możliwości wykonania weryfikujących badań diagnostycznych. Obserwowana w codziennym życiu skłonność mieszkańców wsi do bagatelizowania chorób skóry nasuwa podejrzenie, że szacunki na temat częstości chorób, szczególnie tych mniej uciążliwych, mogą być zaniżone. Ograniczeniem badań przekrojowych jest niemożność weryfikacji diagnozy przez lekarza - objawy chorobowe zwykle są nieobecne w chwili badania, a jeśli nawet są obecne, to lekarz zwykle nie ma możliwości przeprowadzenia pełnej diagnostyki. Przeszkodą w zdobywaniu wiarygodnych danych mogą być też problemy z komunikacją werbalną i zrozumieniem pytań przez badanych, dlatego niezmiernie istotne jest formułowanie pytań językiem prostym, zrozumiałym dla respondenta i jednoznacznym. Podczas zbierania danych należy pilnie obserwować rozmówców i upewniać się, czy zrozumieli pytania zgodnie z intencją badającego (protokołu badawczego). Niezależnie od wymienionych ograniczeń, przedstawione w niniejszej pracy wyniki pokazują, jak duży jest odsetek osób, dla których choroba skóry była uciążliwa na tyle, że uznały ją za problem i zapamiętały.

\section{Wnioski}

Co trzeci dorosły Polak aktualnie choruje bądź chorował w przeszłości na choroby skóry, najczęściej na choroby z kręgu wyprysku oraz trądziku.

\section{Piśmiennictwo}

1. Śpiewak R: Dermatoepidemiologia. W: Śpiewak R (red.). Dermatopedia. URL: http://www.dermatopedia.pl/index. php/indeks-hasel/indeks-a-i/d/91-dermatoepidemiologia (dokument elektroniczny, stan na dzień 11.03.2012).

2. Śpiewak R: Occupational dermatoses in farmers a proposal for diagnostic procedure. Ann Agric Environ Med 1999;6(1):63-72.

3. Śpiewak R: Dolegliwości skórne prowokowane przez pracę w rolnictwie - badania ankietowe 145 rolników z województwa lubelskiego. Post Dermatol Alergol 2001;18(3):194-9.

4. Harnett DL: Statistical methods. Third edition. AddisonWesley Publishing Company, Reading, MA 1982: 326-8.

5. Śpiewak R: Contact dermatitis in atopic individuals. Curr Opin Allergy Clin Immunol 2012;12(5):491-7.

6. Śpiewak R, Kordus K: Podział i definicje chorób z kręgu wyprysku. Int Rev Allergol Clin Immunol 2012;18(4): w druku.

7. Doryńska A, Śpiewak R: Epidemiology of skin diseases from the spectrum of dermatitis and eczema. Malaysian J Dermatol 2012; 29(December): 1-11.

8. Schäfer T, Nienhaus A, Vieluf D, Berger J, Ring J: Epidemiology of acne in the general population: the risk of smoking. Br J Dermatol 2001; 145(1): 100-4.

9. Nowicki R: Grzybica stóp u rolników. Przegl Dermatol 1988; 75(5): 372-4.

10. Gill D, Marks R: A review of the epidemiology of tinea unguium in the community. Australas J Dermatol 1999; 40(1): 6-13.

11. Śsiewak R: Epidemiologia pokrzywek. W: Kruszewski J, Nowicki R, Śpiewak R (red.). Pokrzywki. Rozpoznawanie i leczenie. Stanowisko Panelu Ekspertów Polskiego Towarzystwa Alergologicznego. Medycyna Praktyczna, Kraków 2011: 19-23.

12. Parisi R, Symmons DP, Griffiths CE, Ashcroft DM: Global Epidemiology of Psoriasis: A Systematic Review of Incidence and Prevalence. J Invest Dermatol 2013; 133(2):377-85

13. Plichta D, Doryńska A, Śpiewak R: Wzorce konsumpcji leków oraz występowanie polekowych działań niepożądanych wśród studentów kierunku zdrowie publiczne. Pol Merkuriusz Lek 2012;32(190):232-7.

14. Śpiewak R, Horoch A: Drug intolerance among young Poles. J Invest Dermatol 2006; 126(Suppl 3): s68.

15. Śpiewak R, Bigda M: Drug consumption patterns and the high frequency of adverse drug reactions among students of Public Health. Allergy 2008;63(Suppl 88):618-9.

\section{Finansowanie i konflikt interesów}

Autor deklaruje niewystępowanie konfliktu interesów w odniesieniu do treści zawartych w niniejszej pracy. 


\section{Adres do korespondencji}

Radosław Śpiewak

Instytut Dermatologii

ul. Lentza 6/17

31-312 Kraków

Tel./ Fax: 124166262

E-mail: spiewak.eu@gmail.com
Data złożenia: 13.03.2012

Data akceptacji: 26.05.2012

Data aktualizacji: 30.11.2012

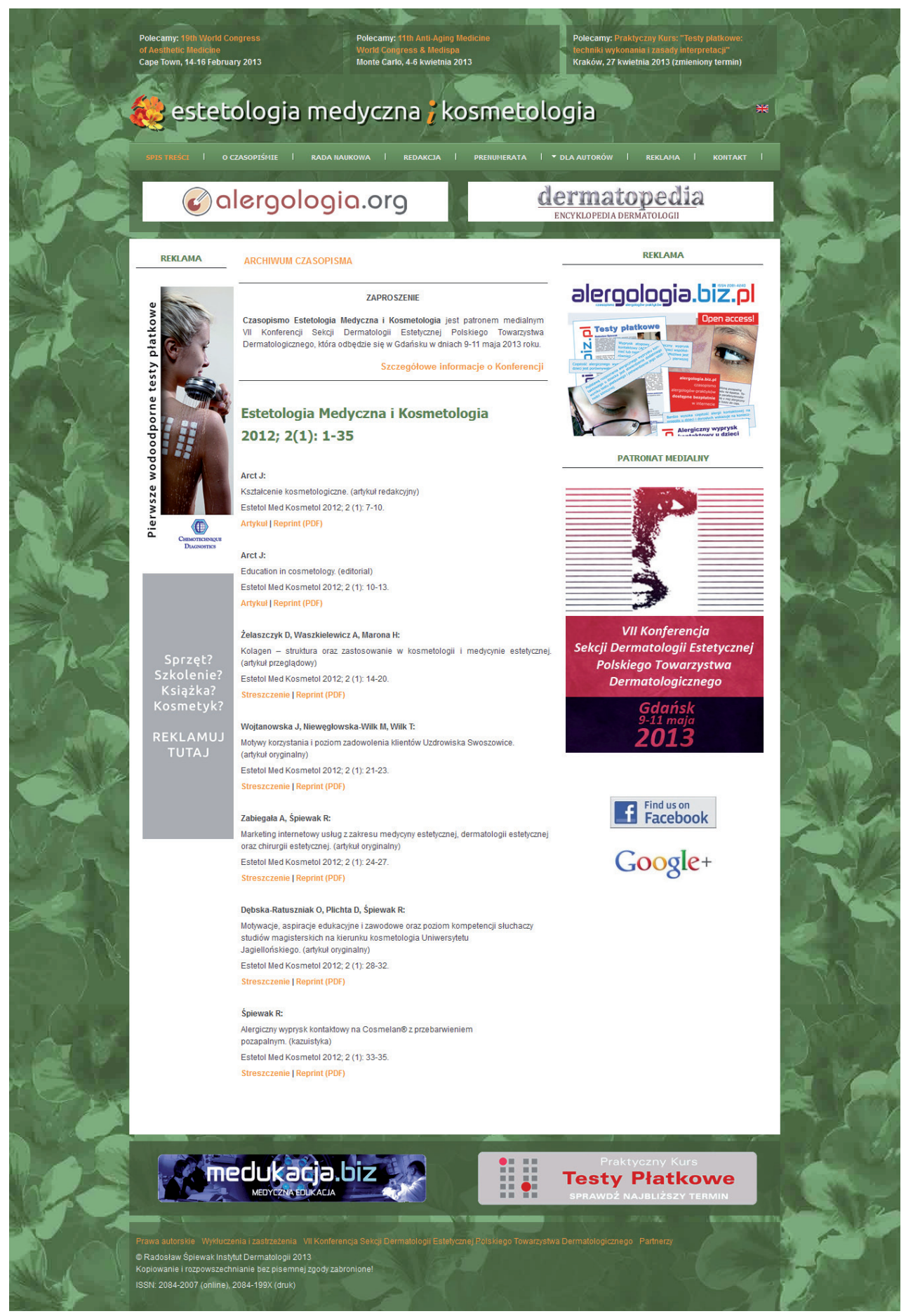

